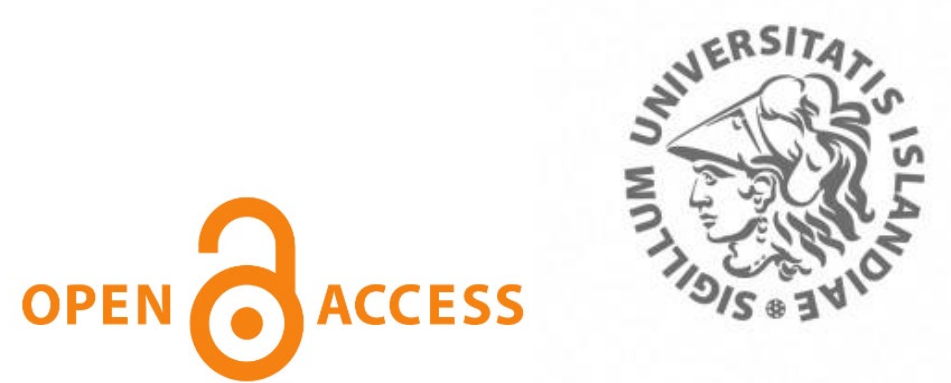

อิ Opin vísindi

This is not the published version of the article / Petta er ekki útgefna útgáfa greinarinnar

Author(s)/Höf.: $\quad$ Laura Malinauskaite, David Cook, Brynhildur Davíđsdóttir and Helga Ögmundardóttir

Title/Titill: $\quad$ Socio-cultural valuation of whale ecosystem services in Skjálfandi Bay, Iceland

Year/Útgáfuár: $\quad 2021$

Version/Útgáfa: $\quad$ Pre-print (óritrýnt handrit)

Please cite the original version:

Vinsamlega vísið til útgefnu greinarinnar:

Malinauskaite, L., Cook, D., Davíđsdóttir, B. \& Ögmundardóttir, H. (2021). Socio-cultural valuation of whale ecosystem services in Skjálfandi Bay, Iceland.

Ecological Economics 180: 106867. DOI:

10.1016/j.ecolecon.2020.106867

Rights/Réttur: $\quad$ C 2020 Elsevier Ltd. All rights reserved 


\title{
Socio-cultural valuation of whale ecosystem services in Skjálfandi Bay, Iceland
}

Laura Malinauskaite (corresponding author), Environment and Natural Resources, Faculty of Life and Environmental Sciences, University of Iceland, Gimli, Sæmundargötu 2, 102 Reykjavík, Iceland, email: lam6@hi.is

David Cook, Environment and Natural Resources, School of Engineering and Natural Sciences, University of Iceland, Gimli, Sæmundargötu 2, 102 Reykjavík, Iceland, email: dac@hi.is

Brynhildur Daviđsdóttir, Environment and Natural Resources, Faculty of Economics and Faculty of Life and Environment Sciences, University of Iceland, Oddi, Sæmundargötu 2, 102 Reykjavík, Iceland, email: bdavids@hi.is

Helga Ögmundardóttir, Faculty of Social and Human Sciences, University of Iceland, Oddi, Sæmundargata 2, 102 Reykjavík, Iceland, email: helgaog@hi.is

\begin{abstract}
The study examines the socio-cultural values of multiple ecosystem services (ES) sourced from whales in Skjálfandi Bay, North Iceland, with many beneficiaries living in and visiting the town of Húsavík. The study begins to address the research gap in non-monetary valuation of marine ecosystem services. Based on a multi-method approach, it elicits stakeholders' perceptions of the contribution of whale ES to human wellbeing using stakeholder mapping, semistructured interviews, observations, and socio-cultural preference surveys. The key whale ES identified by the local stakeholders were cultural, most frequently mentioned being recreation and education. The most commonly mentioned ES values were related to economic benefits from the whale watching industry. The preference survey reveals that regulating and maintenance ES were valued most highly with a mean score of 4.0 out of 5.0, cultural ES were second with a mean score of 3.5, and provisioning ES in the form of food and raw materials were valued the least with a mean of 0.75 . Interview data also reveals some marine ES management challenges originating from intensified tourism, industrial development, and climate change. The results of the study have the potential to inform marine resource management in Iceland by including socio-cultural values associated with whale resources.
\end{abstract}

Keywords: Socio-cultural ES valuation; Whale ecosystem services; Non-monetary valuation; Multi-method approach 


\section{Introduction and case study background}

Ecosystem services (ES) can be valued in biophysical, economic and socio-cultural terms (Martín-López et al., 2014; Pascual et al., 2010). The biophysical value domain is concerned with physical characteristics of ecosystems and their components, the economic - with monetary values of ES, and the socio-cultural - with preferences and principles held by people towards nature (Pascual et al., 2017). The latter are expressed by socially formed and personally held values that cannot be measured in monetary or biophysical terms (MaestreAndrés et al., 2016). These values describe the importance, worth or usefulness of ES to people and can be instrumental, intrinsic or relational depending on the context (Chan et al., 2016; Walz et al., 2019).

A variety of methods are available for assessing socio-cultural values of ES. They are continuously being developed and refined (Martínez et al., 2013; Pascual et al., 2017) and include observational approaches and expert-based approaches, document research, indepth interviews, focus groups, and surveys (Santos-Martín et al., 2017; Scholte et al., 2015). Despite this fact, socio-cultural values have often been overlooked in ES valuation, potentially obscuring human-nature relationships and hampering mainstreaming of the ES concept in policy and management (Chan et al., 2012a; Santos-Martín et al., 2017).

Humans source multiple benefits from whales, including food, tourism, ecosystem regulation, aesthetic enjoyment and artistic inspiration (Cook et al., 2020; Malinauskaite et al., 2020a; Roman et al., 2014). Despite this fact, the ES of marine mammals have been lightly explored in the academic literature. Notably, Roman et al. (2014) and Cook et al. (2020) formed inventories of whale ES, outlining their biological importance. There have also been attempts at economic valuation to assess the recreational value of whale watching (O'Connor et al., 2009; Parsons et al., 2003; Robertsen, 2013). However, whale ES have not yet been assessed from a socio-cultural perspective. Adding this dimension to ES valuation has the potential to deepen the understanding of their role in human wellbeing (Calvet-Mir et al., 2012; de Souza Queiroz et al., 2017).

The uses of whale resources in Iceland have changed considerably in the second half of the twentieth century, with the decline of commercial whaling and increase in whale watching tourism, requiring communities to adapt and change their economic activities accordingly (Einarsson, 2009; Martin, 2012). A community that has so far successfully adapted to the decline of the local fishing industry and increased tourism industry is Húsavík in Northeast Iceland, which is a medium-sized town in northern Iceland and the administrative centre of Norðurping municipality with around 2,500 inhabitants (Statistics Iceland, 2020). It is located around $70 \mathrm{~km}$ south of the Arctic Circle in Skjálfandi Bay (Nicosia \& Perini, 2016) (Figure 1). The fodder-rich bay ecosystem provides feeding grounds for several species of fish, birds, and cetaceans. The main economic activities in Húsavík are fishing and fish processing, agriculture, public services, tourism and other service industries (Nordurthing Municipality, 2020).

The most typical cetacean species observed in Skjálfandi Bay have been minke whales (Balaenoptera acutorostrata), white-beaked dolphins (Lagenorhynchus albirostris), humpback whales (Megaptera novenagliae), harbour porpoises (Phocoena phocoena), blue 
whales (Balaenoptera musculus), fin whales (Balaenoptera physalus) and killer whales (Orcinus orca) (Rasmussen, 2009). Year-round abundance of cetaceans in the bay and the relatively close proximity of their feeding grounds to Húsavík's harbour makes a good spot for whale watching, which became the main tourist attraction in the area soon after its inception in the 1990s (Nicosia \& Perini, 2016).

The number of whale watchers in Húsavík has increased almost fourfold in the last two decades: from around 29,000 in 2003 (when visitor data started to be collected) to 104,000 in 2019 , constituting $28.5 \%$ of all whale watching trips in Iceland, and around $5.2 \%$ of all foreign visitors (Icelandic Tourist Board, 2020). Recognising the growing importance of whale watching for the Icelandic economy, the Icelandic Government designated two whale sanctuaries in the nation's most popular whale watching areas: one in Faxaflói Bay and one in Skjálfandi Bay (Government of Iceland, 2017) (Fig.1). 


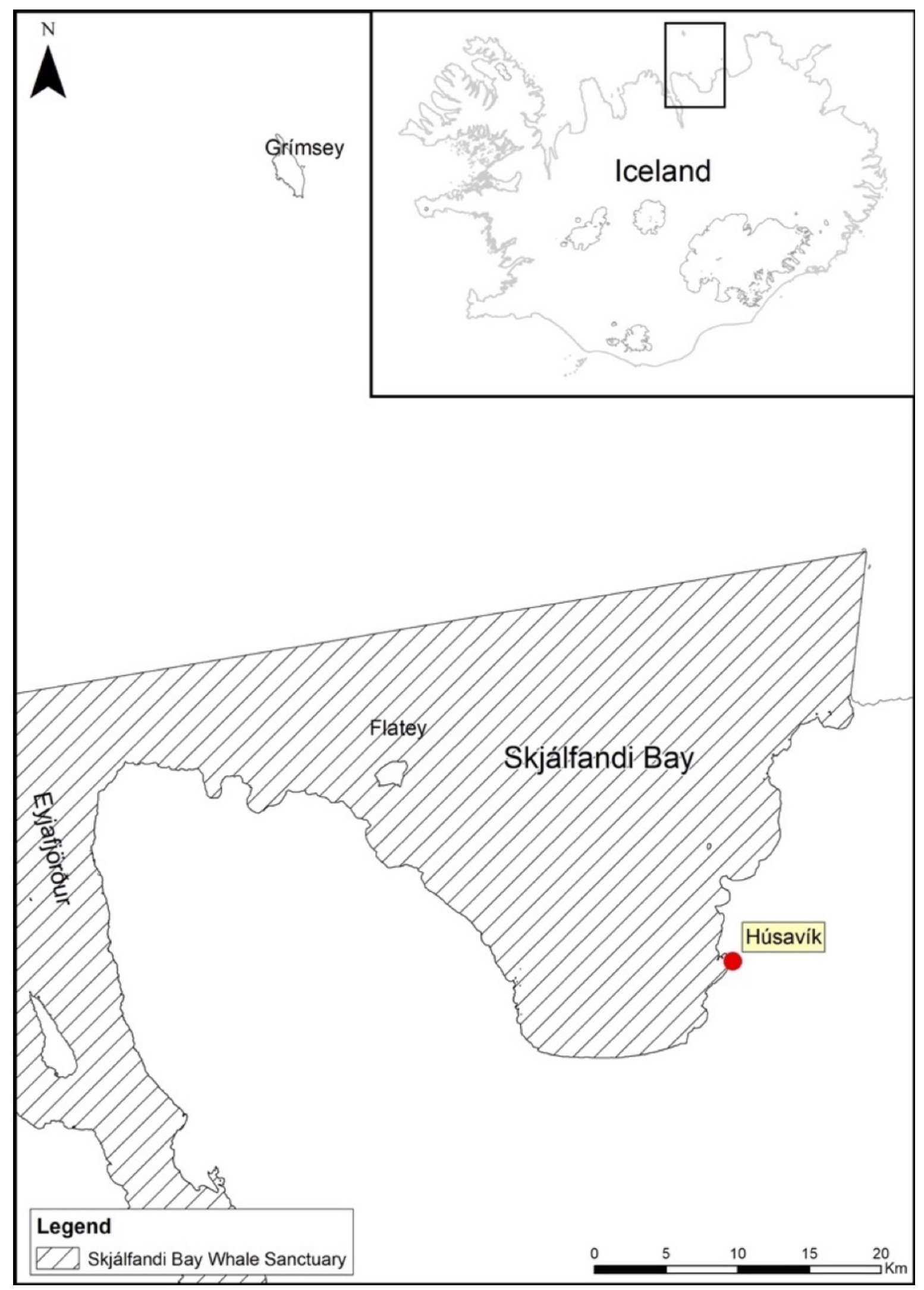

Figure 1. The boundaries of Skjálfandi Bay Whale Sanctuary 
This study responds to the need for more primary ES valuation studies in Arctic socialecological contexts (Malinauskaite et al., 2019). It presents the first attempt to apply sociocultural valuation in the context of the marine environment in Iceland, exploring the multiple values assigned by a coastal community and its visitors to whale ES, and complementing the biophysical and economic data on the role of cetaceans in Iceland's marine environment and economy (IoES, 2019; Rasmussen, 2014). It does so by combining some of the methods typically used in socio-cultural ES valuation.

The study aims to capture and analyse how inhabitants and visitors of Húsavík perceive and value whale ES in socio-cultural terms. The main objectives of the study are (i) to identify the key ES provided by whales in Skjálfandi Bay and the different place-based values that stakeholders assign to them; and (ii) assess the relative importance of key whale ES from a socio-cultural perspective and the factors that influence it. The paper consists of five sections: Section 2 describes the methods used; Section 3 presents the study results, which are then discussed in Section 4, putting them into a wider context; and the final section concludes the paper, drawing attention to the main findings and future research possibilities.

\section{Methods}

Unlike in the case of monetary ES valuation, a standard set of methods has not been developed for socio-cultural valuation. Different approaches have been used to assess various aspects of socio-cultural ES values, such as the social and environmental context and relationships between ES beneficiaries and ecosystems (Scholte et al., 2015). Therefore, multiple valuation techniques can be used to uncover the different dimensions of ES values (Santos-Martín et al., 2017). Five different research methods were applied in this study: a literature review, stakeholder mapping, observations, interviews, and a preference survey. They are listed in Table 1 together with the corresponding research aims. Some of the research activities were carried out simultaneously during fieldwork and were used to inform each other.

Table 1 Research aims and methods

\begin{tabular}{|l|c|l|}
\cline { 2 - 3 } \multicolumn{1}{l|}{} & \multicolumn{2}{l|}{ Research aims } \\
\hline Research methods & $\begin{array}{l}\text { (i) to identify the key ES } \\
\text { provided by whales in } \\
\text { Skjálfandi Bay and values } \\
\text { associated with them }\end{array}$ & $\begin{array}{l}\text { (ii) to assess the relative importance of } \\
\text { ten key whale ES from a socio-cultural } \\
\text { perspective and the factors that } \\
\text { influence their valuation }\end{array}$ \\
\hline Literature review & $\mathrm{X}$ & $\mathrm{x}$ \\
\hline Stakeholder mapping & $\mathrm{X}$ & $\mathrm{x}$ \\
\hline Observations & $\mathrm{X}$ & $\mathrm{x}$ \\
\hline Semi-structured interviews & $\mathrm{X}$ & \\
\hline Preference survey & & \\
\hline
\end{tabular}

\subsection{Literature review}

The purpose of the literature review was to familiarise with the literature on whale ES and their valuation, and sources that could potentially help in fulfilling the study aims. Both 
academic and grey literature was consulted ${ }^{1}$, including academic journal articles, books, historical sources, online news outlets, and websites. The snowball technique was applied in the literature review, meaning that the initial data sources were used to find more sources (Greenhalgh \& Peacock, 2005; Malinauskaite et al., 2019). The technique extended to the semi-structured interviews in the cases where interviewees pointed out additional sources of data.

\subsection{Stakeholder mapping}

The literature review and four initial interviews with experts in the field of whale resources in Iceland were used to identify the key stakeholders in Iceland and Skjálfandi Bay specifically. The process was ongoing, and the stakeholder map (see Appendix 1) developed in tandem with the data collection as interviewees pointed to other people that could potentially be interviewed. The best practice guides for stakeholder identification and mapping were used (Durham et al., 2014; Reed et al., 2009). The stakeholders were grouped into two subgroups, with economic interest (benefitting economically from whale resources) and non-economic interest (having a stake in whale resources other than economic gains, e.g. management, research or activism) in whale ES. Then the former group were split into stakeholders with a direct or indirect economic interest, and the latter bracketed into those with a direct or indirect regulatory interest. The resultant stakeholder map was used to identify the potential interviewees with interest or/and expertise in whale resources in Skjálfandi Bay.

\subsection{Observations}

Observations involved spending time in the case study community and observing everyday activities related to whale ES. Both participant and non-participant observations were conducted (Bessette, 2004), meaning that the authors at times participated in activities such as whale watching, and other times passively observed the activities in the harbour and town. Two one-week-long observations took place in June 2018 and August 2019 when the authors stayed in the community, observed daily activities in the town and participated in some, talked to people during the semi-structured interviews and in informal settings. These observations resemble the ethnographic methods previously used in ES research (Calvet-Mir et al., 2012; Kaltenborn et al., 2017; Maestre-Andrés et al., 2016).

\subsection{Semi-structured interviews}

We aimed to interview as diverse a sample as possible and contacted people in all stakeholder groups. As a result, 15 interviews with 16 local stakeholders ${ }^{2}$ in Húsavík were conducted during the first fieldwork in June 2018. The stakeholder groups represented in the interviews included: whale watching company senior employees $(n=2)$ and whale watching guides $(n=4)$, two of them early career researchers; representatives from the local government $(n=3)$; senior academic researchers focusing on either whale biology or community resilience $(n=2)$; local museum employees $(n=3)$; a senior employee of a local fishing company $(n=1)$; and an owner of a local hospitality business $(n=1)$.

\footnotetext{
${ }^{1}$ The literature was sourced through academic (Google Scholar, Scopus, and Science Direct) and generic (Google) search engines combining the terms 'whale ecosystem services', 'whale watching', 'whaling', 'role of whales' with 'Húsavík', 'Iceland', 'coastal community', 'value', 'social', and 'cultural'.

2 Upon a request by two of the interviewees due to time constraints, they were interviewed at the same time. Interviewees were randomly numbered from I1 to $I 16$ to mark the quotations in the results section.
} 
The interviews were designed with the first research aim in mind: to elicit the key ES provided by whales and values associated with them. Firstly, the interviewees were asked if they were familiar with the concept of ES, and if not, a simple definition was provided. Then, they were asked to describe the most important benefits that people get from whales in Skjálfandi Bay according to their opinion, if they have changed and how. Finally, respondents were asked about their own experience of whale ES and the role they or their organisation play in the use and management of whale ES. Each interview lasted around one hour, the shortest being around 40 minutes, and the longest around 90 minutes. The interviews were mostly conducted in the workplaces of the interviewees, except for a couple which were conducted at a local café.

The interviews were later transcribed in full and coded using the grounded theory inductive approach to qualitative data analysis (Charmaz \& Belgrave, 2007; Glaser \& Strauss, 1967; Strauss \& Corbin, 1990). They were coded using free coding in MAXQDA qualitative analysis software until reoccurring codes, themes and sub-themes emerged, and the codes were systemised accordingly. This allowed for identification and analysis of whale ES and the values assigned to them without pre-conceived terminology, using the interviewees' own words instead (Bullock et al., 2018). The ES and their values elicited during this process were later used to inform the list of the ten key whale ES in the sociocultural survey.

The Common International Classification of Ecosystem Services (CICES) typology (HainesYoung \& Potschin, 2018) was used to classify the key whale ES into provisioning, regulation and maintenance, and cultural. To put the results of the interview analysis in the wider context of the ES literature, the values assigned by the interviewees to whale ES were grouped according to the twelve ES value types as defined by Van Riper and Kyle (2014): aesthetic, biological diversity, cultural, economic, future value, intrinsic, learning, life sustaining, spiritual, recreation, therapeutic, and scientific (Table 4). Furthermore, the identified ES values were also classified into the three value domains typically used by ecological economists - ecological, socio-cultural, and monetary (Gómez-Baggethun \& Martín-López, 2015; Martín-López et al., 2014).

\subsection{Socio-cultural preference surveys}

The socio-cultural preference surveys were conducted by a team of four researchers during the second visit to Húsavík in August 2019. The survey contained a list of ten key whale ES, the importance of which respondents were asked to rank on a Likert-type scale from 0 to 5 0 being not important at all and 5 being very important. Participants were also asked to answer a set of socio-demographic questions. The ten key whale ES were identified through the observations, analysis of the interviews, and the literature review by Cook et al. (2020). The list and characteristics of the whale ES are outlined in Table 2 together with the methodological sources through which they were identified.

Table 2 The key whale ES in the socio-cultural valuation survey

\begin{tabular}{|c|c|c|c|c|}
\hline \multirow[b]{2}{*}{ Ecosystem service } & \multirow[b]{2}{*}{ Characteristics } & \multicolumn{3}{|c|}{ Methodological Source } \\
\hline & & $\begin{array}{l}\text { Inter } \\
\text { views }\end{array}$ & $\begin{array}{c}\text { Observ } \\
\text { ations }\end{array}$ & $\begin{array}{c}\text { Lit. } \\
\text { review }\end{array}$ \\
\hline \multicolumn{5}{|l|}{ Provisioning ES } \\
\hline Food products and raw materials & Whale food products: meat, blubber, skin, etc. & $x$ & & $x$ \\
\hline Regulating and maintenance ES & & & & \\
\hline
\end{tabular}




\begin{tabular}{|c|c|c|c|c|}
\hline Nutrient cycling & $\begin{array}{l}\text { Redistributing nutrients vertically and } \\
\text { horizontally while feeding and defecating. }\end{array}$ & & & $x$ \\
\hline Biodiversity enhancement & $\begin{array}{l}\text { Maintaining nursery populations and habitats } \\
\text { (including gene pool protection). }\end{array}$ & $x$ & & $\mathrm{x}$ \\
\hline \multicolumn{5}{|l|}{ Cultural ES } \\
\hline Recreation and tourism & $\begin{array}{c}\text { Whale watching and other whale-related } \\
\text { tourist activities. }\end{array}$ & $x$ & $x$ & $\mathrm{x}$ \\
\hline Community and cultural identity & $\begin{array}{l}\text { Whales as a source of cultural heritage, social } \\
\text { cohesion and identity. }\end{array}$ & $x$ & $x$ & \\
\hline Spiritual enrichment & $\begin{array}{c}\text { Interactions to which people give spiritual and } \\
\text { symbolic meaning; experience of connection to } \\
\text { nature. }\end{array}$ & & & $\mathrm{x}$ \\
\hline Inspiration for arts & Features of whales that inspire arts. & & $x$ & $\mathrm{x}$ \\
\hline Education & $\begin{array}{c}\text { Direct or indirect interactions enabling } \\
\text { cognitive development, education and training. }\end{array}$ & $x$ & $x$ & $\mathrm{x}$ \\
\hline Aesthetics & Aesthetic experiences. & $\mathrm{x}$ & $\mathrm{x}$ & $x$ \\
\hline Existence & 'Knowing that whales are there'. & $x$ & & $x$ \\
\hline
\end{tabular}

Socio-demographic questions following the best practices in ES valuation, including a standard set of questions about participants' age, gender, level of income, education, number of children, marital status, and residency (Calvet-Mir et al., 2012; Maestre-Andrés et al., 2016; Malinauskaite et al., 2020b). The interviewees and their colleagues were targeted first: employees of municipalities, museums, whale watching companies, the local research centre, tourism businesses etc. Then the general population of Húsavík was targeted in public places, such as the harbour area, local library, swimming pool, cafés, museums, and shops. However, since Húsavík is very popular with foreign visitors and the month of August is within the peak tourist season, it was inevitable that more visitors than locals were targeted as there were more of them present in the public areas.

The results of the survey were analysed using STATA statistical analysis software, eliciting the mean socio-cultural importance scores of the ten whale ES and their relationship to the sociodemographic variables using OLS regression. Since there are very few socio-cultural ES valuation studies to date, the study is exploratory, and results were allowed to emerge from the data rather than from a preconceived hypothesis. Eight socio-demographic dummy variables were used in the OLS regression model to determine statistically significant determinants of the socio-cultural preference scores for each whale ES. The explanations of the variable codes are provided in Table 3. Finally, a two-sample t test was applied to compare the scores assigned by locals and visitors and verify whether there are any significant differences between the means.

Table 3 OLS regression model - predictor variables and coding

\begin{tabular}{|l|l|}
\hline Predictor variable & Explanation of coding \\
\hline Sociodemographic variables \\
\hline Children & A dummy variable, with $0=$ no children under 18 and 1 = at least one child. \\
\hline Education & $\begin{array}{l}\text { A dummy variable, with } 0=\text { no degree education and } 1 \text { = at least an undergraduate } \\
\text { degree. }\end{array}$ \\
\hline $\begin{array}{l}\text { Participation in labour } \\
\text { market }\end{array}$ & $\begin{array}{l}\text { A dummy variable, with } 0=\text { not actively participating in the job market at the time } \\
\text { of the survey and } 1 \text { = active participant. Non-participation includes students, the } \\
\text { retired, sick or disabled, carers, people on maternity/paternity leave and the } \\
\text { unemployed, while active participation included all employed and self-employed } \\
\text { individuals, irrespective of part-time or full time. }\end{array}$ \\
\hline
\end{tabular}




\begin{tabular}{|l|l|}
\hline Gender & A dummy variable, with $0=$ female and $1=$ male. \\
\hline Disposable income & $\begin{array}{l}\text { A dummy variable, with } 0=\text { disposable income under } 500,000 \text { ISK and } 1= \\
\text { disposable income over } 500,000 \text { ISK. }\end{array}$ \\
\hline Age & A dummy variable, with $0=$ not older than 50 and $1=$ older than 50. \\
\hline $\begin{array}{l}\text { Marital status/ } \\
\text { cohabitation }\end{array}$ & $\begin{array}{l}\text { A dummy variable, with } 0=\text { not married or cohabiting with a partner and } 1= \\
\text { married or cohabiting. }\end{array}$ \\
\hline Residence & $\begin{array}{l}\text { A dummy variable, with } 0=\text { resident of Húsavík and } 1=\text { residence outside of the } \\
\text { town. }\end{array}$ \\
\hline
\end{tabular}

\section{Results}

The results of the study are presented below: the whale ES that emerged from the analysis of the interviews, the values corresponding to whale ES in the context of established ES value classifications in the literature, the results of the socio-cultural valuation survey, significant socio-demographic variables, and some additional issues emerging from the interviews.

\subsection{ES identified through analysis of the interviews}

The analysis of the interviews revealed that the whale ES mentioned by most ${ }^{3}$ interviewees were tourism and recreation $(n=10)$ and education $(n=10)$, followed by the role the whales play in local community cohesiveness and identity $(n=8)$, aesthetic enjoyment $(n=5)$, and whale food products $(n=5)$ (Table 4). Ecosystem support $(n=2)$ and existence value-related whale ES $(n=3)$ were mentioned by two and three respondents respectively, and one respondent elaborated on the role of whales in spiritual experiences of local ecosystems $(n=1)$ and inspiration for arts $(n=1)$. This information was used in conjunction with the literature review and classification of whale ES by Cook et al. (2020) to select ten ${ }^{4}$ key whale ES that were later used in the socio-cultural valuation survey (see the list in Table 5).

The interviewees used their own words to describe ES values, attaching them to particular ES. Therefore, the phrases used to describe values and related services partly but not entirely coincide (Table 4). However, there is a distinction between ES and their values: for instance, provisioning ES in the form of whale meat were mentioned by three interviewees but only one of them assigned a nutritional value to it. The identified values were put into a context by classifying them into different types (Van Riper \& Kyle, 2014) and domains (Martín-López et al., 2014). This allowed for a comparison of the study results to other ES valuation studies that include multiple values.

Table 4 Ecosystem services and types of assigned values identified in the interviews

\begin{tabular}{|l|l|l|l|l|l|l|l|l|}
\hline ES Identified & CICES Group & Number & Percent & $\begin{array}{l}\text { ES Value } \\
\text { Identified }\end{array}$ & Value Type & Value Domain & Number & Percent \\
\hline $\begin{array}{l}\text { Tourism \& } \\
\text { recreation }\end{array}$ & Cultural & 10 & $62.50 \%$ & Economic & Economic & Monetary & 16 & $100.00 \%$ \\
\hline
\end{tabular}

\footnotetext{
${ }^{3}$ Even though the interview data analysis using MAXQDA software revealed both how many respondents mentioned each ES as well as the frequency and extent of discussion by each respondent, one mention per interviewee was counted regardless of how many times the same ES was mentioned or to what extent it was discussed by the same person. The reasoning behind this was to give each respondent equal weight in the analysis.

${ }^{4}$ Seven ES that were mentioned in the interviews are listed in Table 4.
} 


\begin{tabular}{|l|l|l|l|l|l|l|l|l|}
\hline $\begin{array}{l}\text { Knowledge \& } \\
\text { education }\end{array}$ & Cultural & 10 & $62.50 \%$ & Educational & $\begin{array}{l}\text { Learning \& } \\
\text { Scientific }\end{array}$ & Socio-cultural & 10 & $62.50 \%$ \\
\hline $\begin{array}{l}\text { Community } \\
\text { identity \& } \\
\text { cohesion }\end{array}$ & Cultural & 8 & $50.00 \%$ & $\begin{array}{l}\text { Socially } \\
\text { formed }\end{array}$ & Cultural & Socio-cultural & 10 & $62.50 \%$ \\
\hline $\begin{array}{l}\text { Aesthetic } \\
\text { enjoyment }\end{array}$ & Cultural & 5 & $31.25 \%$ & Aesthetic & Aesthetic & Socio-cultural & 5 & $31.25 \%$ \\
\hline Existence & Cultural & 3 & $18.75 \%$ & Existence & Intrinsic & Socio-cultural & 3 & $18.75 \%$ \\
\hline Whale meat & Provisioning & 5 & $31.25 \%$ & Nutritional & $\begin{array}{l}\text { Life- } \\
\text { sustaining }\end{array}$ & Biophysical & 1 & $6.25 \%$ \\
\hline $\begin{array}{l}\text { Ecosystem } \\
\text { regulation }\end{array}$ & $\begin{array}{l}\text { Regulation \& } \\
\text { maintenance }\end{array}$ & 2 & $12.50 \%$ & Ecological & $\begin{array}{l}\text { Biological } \\
\text { diversity }\end{array}$ & Biophysical & 2 & $12.50 \%$ \\
\hline
\end{tabular}

Tourism and recreation and educational ES were discussed most extensively by the interviewees as the main visitor attractions in Húsavík are whale watching and the Whale Museum. The interviews indicate that these two whale ES form a synergy as expanding tourism results in more visitors who often ask locals about whales and the surrounding ecosystems, increasing interest of the locals in their marine environment and facilitating local learning: 'you would walk into the bookstore in Húsavík and there was a tourist telling you 'oh, did you know there are these and those whales in your bay?', and I thought it should be like vice versa'(16).

Educational ES are generated in whale watching trips where participants not only get to see whales but also learn about other species and the whole ecosystem, in this way enhancing their environmental awareness. Moreover, the Whale School is organised jointly by the Whale Museum and the local primary school for its pupils to get acquainted with the biodiversity of Skjálfandi Bay: 'the purpose was that people like children in Húsavík would know the whales and know why they are here' (16).

An additional point of synergy between recreational and educational whale ES is the cooperation between the whale watching sector and the University of Iceland's Research Centre in Húsavík, which attracts young and motivated researchers who have the opportunity to simultaneously do research and make a living as whale watching guides. This puts Húsavík on the map for marine mammal research, increasing its socio-demographic diversity: 'Húsavík is like a magnet for young educated people, and it's all due to the whale watching and the activities around the whale watching.' (I12); 'the opportunity for the whale-watching and the research here is huge' (I3).

Community cohesiveness and identity was discussed by half of the interviewees in the context of the transformation of Húsavík from a fishing to whale watching town. Whale watching created new opportunities for the local people not only to make a living locally but also redefine itself as a community with a whale as a new symbol of the town. As one interviewee expressed it: 'it's like a part of the image we have of ourselves - it's the whales and they're important, and we kind of like them because of that' (I14).

Whales are known to inspire admiration, respect and awe due to their aesthetic characteristics, such as majestic appearance and large size (Cook et al., 2020). A whale watching guide noted: 'I've had people getting emotional on the boat, they're just so overwhelmed by what they're seeing' (14). Cetaceans have been known to also inspire art and 
music in different parts of the world for centuries (ibid., Sakakibara, 2009). Whales have inspired local art in Húsavík (noticed during observations), which was the motivation behind including the 'inspiration for arts' to the list of ten key whale ES.

ES associated with existence values were mentioned by only three people, which may be because existence is perceived as less tangible than other ES with tangible products, such as recreation and tourism. However, this ES was the only one that did not receive a single 0 mark on the Likert-scale in the preference survey and was the highest-rated cultural ES. It was expressed by one interviewee that it is the first animal that became a symbol of maltreatment of the natural living world, globally' (I5), also indicating a symbolic value of this ES. Regulating and maintenance ES were only mentioned by a couple of respondents but were the most highly valued group of ES in the socio-cultural survey, which perhaps indicates rather a lack of awareness than perception of limited importance.

Provisioning ES in the form of whale meat were mostly referred to as a thing of the past that is fading away quickly, having lost their cultural and economic significance. Unlike in Faxaflói Bay in Southwest Iceland, whaling has never been an important economic or cultural activity in Skjálfandi Bay. Some of the interviewees mentioned harvested minke whales being brought to Húsavík harbour a few times a year for local consumption, which were either a product of a by-catch or hunting: 'I remember one or two times going to the harbour where there was a whale that has either been killed or stranded, and people were getting meat from it' (I6).

\subsection{ES values identified in qualitative analysis of the interviews}

When referring to tourism and recreation ES values, the interviewees mostly did so in terms of economic benefits for the Húsavík community and not recreational values that reflect the interests of visitors. This demonstrates the difficulty in translating locally formed values to standardised ES classification frameworks, an issue that was also noted by de Souza Queiroz et al. (2017). All respondents mentioned the economic values $(n=16)$ that the Húsavík community receives from whales through income and employment opportunities in the tourism sector, as the following quotations illustrate: 'if it weren't for the whale watching industry, I think this town would be basically dead' (14); 'fishermen who lost their jobs in the fishing industry and have gotten employment in whale watching' (I5); 'let's say 90 percent of all my guests are here because of whale watching' (17).

Socially formed values $(n=10)$, such as community identity, social cohesion, and connection to nature, were mentioned by ten respondents, as were educational values. The number of mentions of aesthetic $(n=5)$ and existence $(n=3)$ values coincided with the number of times whale ES associated with them were mentioned. This is due to the characteristics of these ES that relate to specific kinds of values. Biophysical values $(n=3)$ were related to the ecological functions of whales and nutritional benefits.

\subsection{Preference survey results}


The survey was completed by a total of 589 people, 105 of them local residents of Húsavík and 484 visitors. Not all of the respondents completed all of the survey questions, and this resulted in differing numbers of observations for most $\mathrm{ES}^{5}$. Table 5 lists the results of the socio-cultural survey: the mean scores of the key whale ES, together with number of observations and standard deviations for three groups - the whole sample, Húsavík residents, and visitors. Figure 2 lists the mean ES scores and standard deviations of the whole sample.

Table 5 Mean scores of the ten key whale ES identified by survey respondents

\begin{tabular}{|l|l|l|l|l|l|l|l|l|l|}
\hline & \multicolumn{2}{l}{ Total } & \multicolumn{2}{l|}{ Locals } & \multicolumn{2}{l}{ Visitors } \\
\hline $\begin{array}{l}\text { Ecosystem service } \\
\text { (CICES classification) }\end{array}$ & $\begin{array}{l}\text { Mean } \\
\text { total }\end{array}$ & $\begin{array}{l}\text { No. } \\
\text { obs. }\end{array}$ & $\begin{array}{l}\text { Standard } \\
\text { deviation }\end{array}$ & $\begin{array}{l}\text { Mean } \\
\text { locals }\end{array}$ & $\begin{array}{l}\text { No. } \\
\text { obs. }\end{array}$ & $\begin{array}{l}\text { Standard } \\
\text { deviation }\end{array}$ & $\begin{array}{l}\text { Mean } \\
\text { visitors }\end{array}$ & $\begin{array}{l}\text { No. } \\
\text { obs. }\end{array}$ & $\begin{array}{l}\text { Standard } \\
\text { deviation }\end{array}$ \\
\hline Provisioning ES & $\mathbf{0 . 7 4 7}$ & & $\mathbf{1 . 3 8 0}$ & $\mathbf{0 . 7 2 4}$ & & $\mathbf{1 . 2 2 9}$ & $\mathbf{0 . 7 3 7}$ & & $\mathbf{1 . 3 9 1}$ \\
\hline Food products and raw materials & 0.747 & 589 & 1.380 & 0.724 & 105 & 1.229 & 0.737 & 472 & 1.391 \\
\hline Regulating and maintenance ES & $\mathbf{4 . 0 0 3}$ & & $\mathbf{1 . 2 5 4}$ & $\mathbf{3 . 8 1 0}$ & & $\mathbf{1 . 2 2 7}$ & $\mathbf{4 . 0 4 6}$ & & $\mathbf{1 . 2 5 4}$ \\
\hline Nutrient cycling & 3.690 & 588 & 1.508 & 3.533 & 105 & 1.409 & 3.715 & 471 & 1.531 \\
\hline Biodiversity enhancement & 4.316 & 585 & 0.999 & 4.087 & 104 & 1.044 & 4.377 & 469 & 0.976 \\
\hline Cultural ES & $\mathbf{3 . 5 2 5}$ & & $\mathbf{1 . 2 6 3}$ & $\mathbf{3 . 4 4 9}$ & & $\mathbf{1 . 3 1 0}$ & $\mathbf{3 . 5 3 1}$ & & $\mathbf{1 . 3 3 4}$ \\
\hline Recreation and tourism & 3.418 & 588 & 1.338 & 3.705 & 105 & 1.255 & 3.365 & 471 & 1.344 \\
\hline Community and cultural identity & 3.661 & 587 & 1.155 & 3.552 & 105 & 1.101 & 3.677 & 470 & 1.160 \\
\hline Spiritual enrichment & 2.631 & 582 & 1.601 & 2.592 & 103 & 1.746 & 2.617 & 467 & 1.570 \\
\hline Inspiration for arts & 2.983 & 586 & 1.377 & 2.923 & 104 & 1.446 & 2.974 & 470 & 1.355 \\
\hline Education & 4.044 & 588 & 1.077 & 3.905 & 105 & 1.156 & 4.062 & 471 & 1.063 \\
\hline Aesthetics & 3.523 & 587 & 1.396 & 3.248 & 105 & 1.486 & 3.581 & 470 & 1.359 \\
\hline Existence & 4.404 & 587 & 0.900 & 4.219 & 105 & 0.990 & 4.438 & 470 & 0.881 \\
\hline
\end{tabular}

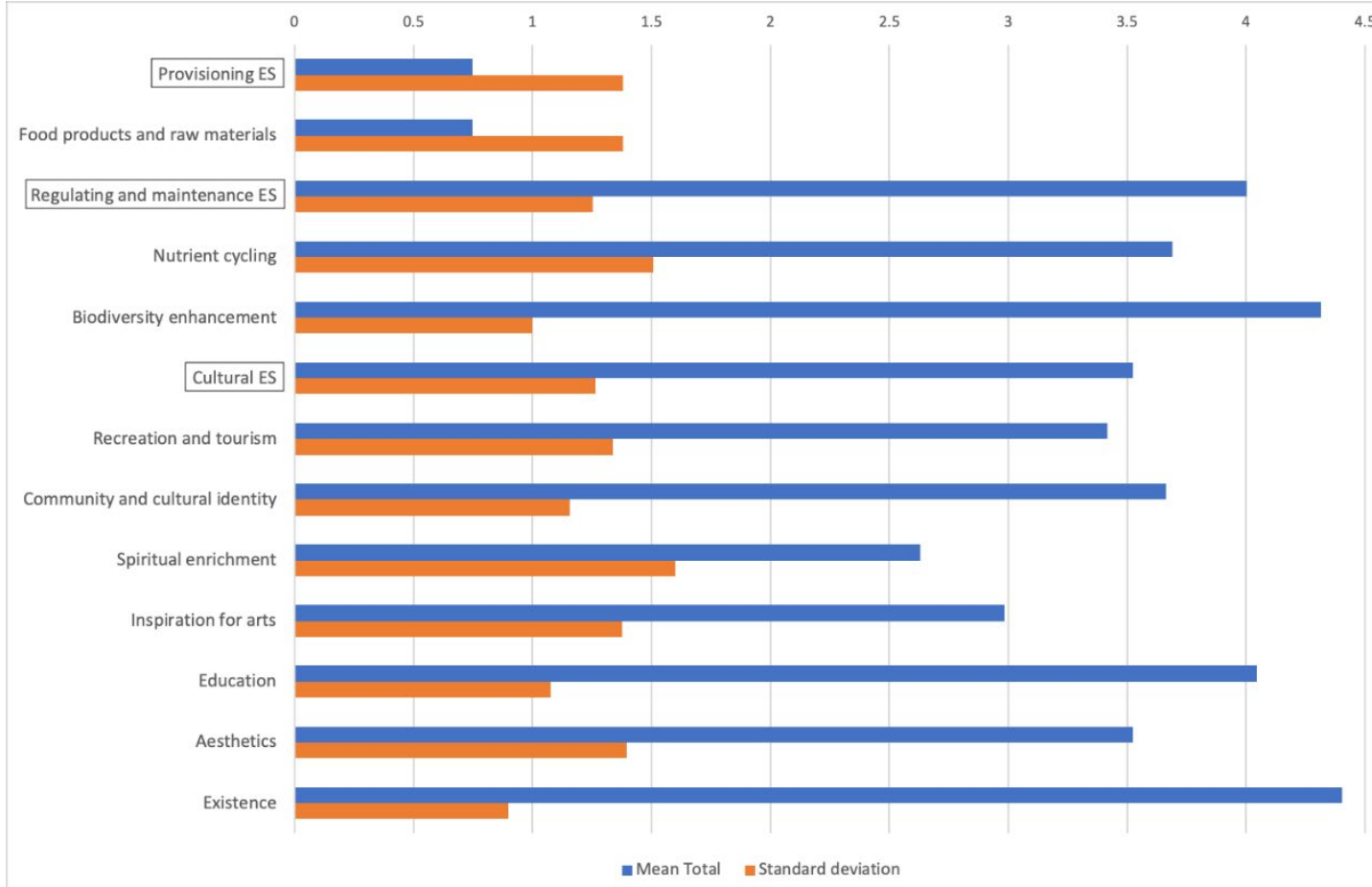

Figure 2 Mean scores and standard deviations of the ten key whale ES and ES categories

\footnotetext{
${ }^{5}$ E.g. twelve respondents did not declare their place of residence, resulting in them being included in the total sample but not in the two sub-samples of Húsavík locals and visitors.
} 
The survey results suggest that whale ES associated with existence values were the most valued. The second highest-rated ES was biodiversity enhancement associated with the presence of whales in the bay, followed by education, nutrient cycling, community cohesion, and recreation and tourism. Overall, regulating and maintenance ES were the most highly valued of the three groups of whale ES with an overall mean score of 4.00 , and provisioning ES were the least highly valued with a mean score of 0.75 . The mean score of the cultural ES group was 3.53. The highest standard deviation of 1.38 was observed for provisioning ES, while regulating and maintenance and cultural ES had standard deviations of 1.25 and 1.26, respectively. The highest standard deviation occurred for ES related to spiritual enrichment, nutrient cycling, food and raw materials, and aesthetics.

Húsavík residents valued recreation and tourism ES significantly more than visitors, which is also reflected in the interviews and is hardly surprising, given that whale watching is the main source of income in the local tourism industry. Visitors gave higher scores to biodiversity enhancement, education, aesthetics and existence $\mathrm{ES}^{6}$. Regulation and maintenance ES were highest rated despite being the least frequently mentioned in the interviews. These ES were also the ones that needed the most explanation during the socio-cultural survey implementation, and when explained were usually rated relatively highly.

\subsection{OLS regression model outcomes}

Table 6 presents the results of the OLS regression analysis of the whole sample ${ }^{7}$ using the socio-demographic variables listed in the methods section (Table 3). For each of the statistically significant variables, the coefficients and standard errors are listed for each of the ten whale ES from the socio-cultural preference survey. In accordance with the approach of Maestre-Andrés et al. (2016), only the statistically significant socio-demographic variables are displayed.

Table 6 OLS regression results of the socio-cultural preference survey

\begin{tabular}{|c|c|c|}
\hline Ecosystem service & Significant variables & Coefficient (Std. Error) \\
\hline \multicolumn{3}{|l|}{ Provisioning ES } \\
\hline \multirow[t]{3}{*}{ Food products and raw materials } & Education $* *$ p 0.041 & $0.274(0.136)$ \\
\hline & Gender*** p 0.008 & $0.320(0.120)$ \\
\hline & Income $* * *$ p 0.002 & $-0.427(0.139)$ \\
\hline \multicolumn{3}{|l|}{ Regulating and maintenance ES } \\
\hline Nutrient cycling & Marital status* p 0.084 & $-0.281(0.163)$ \\
\hline \multirow[t]{2}{*}{ Biodiversity enhancement } & Children** p 0.027 & $-0.243(0.100)$ \\
\hline & Education*** p 0.000 & $0.383(0.101)$ \\
\hline \multicolumn{3}{|l|}{ Cultural ES } \\
\hline \multirow[t]{2}{*}{ Recreation and tourism } & Income $* * *$ p 0.000 & $0.508(0.139)$ \\
\hline & Residency*** p 0.005 & $0.436(0.154)$ \\
\hline
\end{tabular}

\footnotetext{
${ }^{6}$ Two-sample t-test revealed significant differences between Húsavík locals and visitors in valuing five whale ES: biodiversity enhancement and tourism and recreation ES were significant at $1 \%$ level; ES associated with aesthetics and existence values at $5 \%$ level; and education at $10 \%$ level.

${ }^{7}$ It is important to note that the survey sample is not necessarily representative of one population but is rather a mixture of visitors and locals that agreed to be surveyed during the week of fieldwork. While the study provides a snapshot of how whale ES are valued in Húsavík from a socio-cultural point of view, wider generalisations are avoided.
} 


\begin{tabular}{|l|l|l|}
\hline Community and cultural identity & - & - \\
\hline Spiritual enrichment & Education*** p 0.000 & $0.614(0.174)$ \\
\hline & Age*** 0.002 & $0.558(0.177)$ \\
\hline Inspiration for arts & Education** p 0.041 & $0.286(1.400)$ \\
\hline Education & Children** p 0.014 & $-0.293(0.119)$ \\
\hline & Income* $^{*} 0.096$ & $0.192(0.115)$ \\
\hline Aesthetics & Age** p 0.032 & $0.326(0.152)$ \\
\hline Existence & Age** p 0.023 & $0.233(0.102)$ \\
\hline
\end{tabular}

$* * *$ indicates significance at $1 \%$ level; ${ }^{* *}$ significance at $5 \%$ level, and ${ }^{*}$ at $10 \%$ level.

The most significant socio-demographic variables for provisioning ES were income and gender, both significant at the $1 \%$ level. Education was significant at the $5 \%$ level, implying that respondents with university-level education valued provisioning ES more. Male respondents and those with university-level education were more likely to give higher value scores to the provisioning ES, while those with higher income - lower scores.

Respondents who were married or in cohabitation with a partner and those who had children under 18 valued regulating and maintenance ES relatively less, while those with a higher level of education did so significantly more. Education, income, age, having children under 18, and residing in Húsavík were all significant variables for valuing cultural whale ES. Respondents with relatively higher income and Húsavík residents gave higher scores to recreation and tourism. Older and university educated residents valued spiritual enrichment more highly; university educated respondents also gave higher scores to inspiration for arts. Those with no children under 18 valued education ES higher, and those with high income - lower. Being over 50 was positively correlated with higher values for aesthetics and existence. The only cultural whale ES that did not have any significant socio-demographic variables was community and cultural identity.

\subsection{Shifting perceptions and threats associated with whale ES in Skjálfandi Bay}

The interviews and stakeholder mapping revealed a number of issues related to socio-cultural values of whales in the area. Interview data shows that these values have been changing rapidly in tandem with socio-economic changes in Húsavík and Iceland, the biggest change being the shift from the fishing industry to tourism, which was brought up and discussed in some detail by eleven interviewees, all of them native to the area. Changes in individual perceptions and attitudes towards whales and their ES were discussed by twelve of the fifteen interviewees. As one of the interviewees expressed it: 'more and more people understand the true benefits of having a booming tourism industry in town, because a lot of the things that come along with it: increased the standard of living, the things we can do, simply the quality of life' (I10).

Generational differences in these attitudes, and differences among stakeholders, especially between locals and visitors, were discussed most frequently. These changes were not always described as straight-forward but as a shift from provisioning to cultural whale ES. This trend is pertained by the following quotes: 'I think that maybe 20 years ago it was not something special to see a whale, but now people are thinking more about whales.' (I15); 'There is a new generation of people in Iceland who see that whaling is not the only way of relating to or 
using whales. So that is [...] thanks to the whale watching, obviously; it has opened up the eyes of Icelanders that there are alternatives.' (I12)

Seven interviewees mentioned noticing changes in whale species composition and abundance in Skjálfandi Bay since the start of whale watching, and five interviewees linked them to climate change. An interviewee noted that: 'In the first years the whale watching was built up from mostly showing minke whales, though there were occasional humpbacks. Since then, there are many more humpbacks, and blue whales are coming to visit with increasing frequency. [...] It seems to be related to the availability of feed, and climate change plays a part in the changes in feed availability.' (15)

Concerns were expressed by five interviewees from the whale watching industry about the unpredictability of whale sightings that underlie tourism and recreation ES. There was a palpable anxiety that highly migratory whales might leave the area due to climate changeinduced alterations in the distribution of their prey, notably herring and capelin. This had already happened in some areas in the Arctic, including Kaldfjord near Troms $\varnothing$, Norway where one of the Húsavík's whale watching companies had been operating, causing a collapse of whale watching in the area: 'then last year [2017] there were no whales because the herring had moved [...] even further north' (I1).

Unregulated whale watching ${ }^{8}$ was frequently mentioned as another potential threat to cetaceans: 'it is hard to imagine that it is not affecting the whales: it is a lot of noise, and it is a lot of traffic' (I3); 'I mean too many boats chasing too few whales [...] they are obviously breaking the rules all the time, these guidelines that they had so earnestly undersigned.' (I12); 'you can have a boat for 20 hours - if you talk about noise, at least, then it is constant' (I11). Previous studies in Iceland confirm that disturbances occur (Christiansen et al., 2013; Lusseau \& Bejder, 2007), and research on the topic in Skjálfandi Bay is ongoing.

Globalisation also presents negative effects on Arctic marine ecosystems in terms of increased shipping and tourism, especially cruise ships, the climate change effects of increased traveling as well as increased industrial development (Bock, 2013; Chapin et al., 2015; Johannsdottir et al., 2020). In Skjálfandi Bay, there are concerns over how the industrial development might be affecting the local marine ecosystem: 'at sea, it's also about what will happen with the cargo ships and the noise related the new factory, so that's another increase' (I11). In an assessment prior to a construction of a silicon refinery plant, attention was drawn by scientists to the potential effects of noise from increased shipping and chemical discharges from the plant (Rasmussen, 2009).

\section{Discussion}

\subsection{General findings}

\footnotetext{
${ }^{8}$ Whale watching is Iceland is not regulated by law but a voluntary code of conduct was designed and adopted by the Icelandic Whale Watching Association (IceWhale, 2015).
} 
In the light of the existing literature, the results shed some light on how people perceive and value ES associated with whales - an important part of the local social-ecological system - in a northern coastal community. Despite being location-specific and methodologically novel, the results are comparable to studies elsewhere and serve as a step towards including sociocultural values in ES assessments. The results revealed some synergies and trade-offs that can be more easily spotted and quantified on species and functional levels (Beaumont et al., 2007; Hammerschlag et al., 2019; Riisager-Simonsen et al., 2020). The synergies revealed between the ES of tourism and recreation and education and community cohesion suggest that the importance of whale watching in Húsavík extends far beyond economic gains.

There are also possible trade-offs between provisioning and recreational ES in Iceland, as observed by Cook et al. (2020) and Bertulli et al. (2016). Another trade-off within ES is related to unregulated whale watching and the ES of recreation and tourism. This trade-off points to limits to growth of the whale watching industry that has been discussed in the literature, e.g. in Australia (Bejder et al., 2006), New Zealand (Lusseau, 2004), Canada (Williams et al., 2006), and Iceland (Christiansen et al., 2013) that find disruptions in cetacean feeding and breeding activities caused by whale watching. With four whale watching companies operating in Skjálfandi Bay, there is little room to expand even further, even though there are currently no regulations in place to limit the number of boats or tour operators in the bay.

\subsection{Contextualising the study results within the ES literature}

The results of the qualitative analysis of the interviews indicate that whales have become a characteristic and symbolic part of Húsavík, providing new cultural and economic opportunities for a town that had struggled with its identity since the decline of the local fisheries' industry (Chambers et al., 2017; Guðmundsdóttir \& Ívarsson, 2008; Reiter, 2017). It could also be argued that the existence of whales has a more global symbolic meaning for success of environmental protection - if humans are not able to save these flagship species, there may be little hope for others (Mattes, 2017).

In terms of provisioning ES, whaling has never been a big part of the local culture in Húsavík, which partly accounts for its limited importance revealed in this study. Results of a similar study in a location that is heavily dependent on whale meat as a local food source, e.g. Greenland, are likely to be very different (Caulfield, 1997; Malinauskaite et al., 2020a). In terms of regulating and maintanace ES, Maestre-Andrés et al. (2016) also found that ES related to underlying ecological functions of ecosystems tend to be less frequently identified by respondents who possessed no specialist knowledge but assigned relatively high scores in a preference survey when their attention was drawn to them.

Similarly, a lack of awareness of some ES values, such as biophysical and existence, do not necessarily imply their limited importance - but rather limited awareness. Chan et al. (2016) argues that non-instrumental values, such as intrinsic and relational, play a big part in motivating environmental protection, shaping views on personal and collective well-being. Jax et al. (2013) note that existence values tend to be overlooked in ES research, which can result in instrumental values obscuring the intangible wellbeing benefits that originate from non-instrumental values. The fact that survey respondents were often unaware of regulation 
and maintenance ES but rated them highly after explanation indicates lack of knowledge and perception that the terms associated with this ES group are important. High values were also assigned to regulation and maintenance ES in some other socio-cultural valuation studies (de Souza Queiroz et al., 2017; Maestre-Andrés et al., 2016).

The fact that provisioning ES received a relatively low mean score compared to other whale ES indicates a general view that whale meat consumption plays a limited role in terms of the wellbeing of Húsavík inhabitants. Even those interviewees who had grown up eating it admitted that this ES presently has limited importance. Other studies in Iceland also reveal the fading role of provisioning ES sourced from whales. Gallup Iceland's (2017) survey on Icelanders' attitudes to whaling in 2017 indicated that $81.4 \%$ of respondents have not bought whale meat during the twelve months prior to the survey, while only $1 \%$ bought it six times or more, indicating very limited demand. Its consumption nowadays is largely symbolic and takes place in food festivals in winter (Brydon, 2006). A contingent valuation survey in Faxaflói Bay, near the capital of Reykjavík, revealed that only $23 \%$ of the participants thought that whaling was important to the Icelandic economy, as opposed to $48 \%$ that answered the same question about whale watching (Malinauskaite et al., 2020b).

The finding that the ES of tourism and recreation ES were valued more highly by locals than visitors points to its economic importance in the community. A non-monetary valuation study in a coastal area of Bangladesh by Chakraborty et al. (2020) also found that locals valued coastal recreation and tourism ES more than visitors as these services constitute an important part of their livelihoods. Interestingly, community and cultural identity ES were valued more highly by visitors than locals. This might be due to a preconception by visitors about the role of whales in the lives of Húsavík residents that does not necessarily match with local perceptions. Interview data indicates that while local stakeholders are aware of the economic benefits brought by whales, fewer associate these with community cohesion. This ES was discussed by half of the interviewees, which combined with the mean score of 3.55 confirms its socio-cultural significance, albeit it was not rated as highly as in some other similar studies (Calvet-Mir et al., 2012; de Souza Queiroz et al., 2017; Maestre-Andrés et al., 2016).

In terms of significant socio-demographic variables, men were found to be more likely to perceive provisioning ES than women, which has also been found in previous research (Martín-López et al., 2012; Oteros-Rozas et al., 2014). A monetary ES valuation study on the trade-offs between cultural and provisioning whale ES in Iceland found that women were willing to pay more for the expansion of a sanctuary that would limit whaling in the area, as were respondents with higher education (Malinauskaite et al., 2020b). Visitors valued whale meat more than locals, which might be associated with its marketing as a traditional Icelandic food (Bertulli et al., 2016; Huijbens \& Einarsson, 2018) and the absence of whaling in the area.

In accordance to the results of the study, some previous research found higher levels of education to be positively correlated with a deeper understanding of ecosystem functioning and higher socio-cultural valuation scores assigned to regulating and maintenance ES (MartínLópez et al., 2012; Oteros-Rozas et al., 2014). In the present study, having a spouse and children seemed to reduce respondents' emphasis on regulating and maintenance ES. OterosRozas et al. (2014) observed that people prioritise different ES depending on life stages, and 
preferences related to regulating and maintenance ES are likely to change with life experiences, including work and family.

The fact that older people and those with higher education gave higher scores to spiritual enrichment may indicate that these sub-groups of respondents may place more emphasis on the less tangible values of ecosystems because they have had more opportunities to contemplate them, a tendency also noted in other studies (Maestre-Andrés et al., 2016; Oteros-Rozas et al., 2014). Inspiration for arts was the second lowest-rated cultural ES with one significant socio-demographic variable - education. This could also be interpreted as a result of respondents' non-familiarity with the less tangible ES and difficulties assigning values to them, also observed in wider literature (Chan, Guerry, et al., 2012; Chan, Satterfield, et al., 2012).

The mean socio-cultural value scores associated with aesthetics and existence values were both affected by the age of the respondents, which may again indicate that older people are more appreciative of ES which require reflection and contemplation (Oteros-Rozas et al., 2014). The relative importance of 'simply knowing that whales are there' in the survey compared to aesthetic enjoyment perhaps indicates a higher appreciation for intrinsic rather than instrumental values of nature, which aligns with the analysis of (Chan et al., 2016).

Cultural ES represented the largest group of whale ES included in the survey. Even though the respondents were asked to assess different cultural ES individually, they are often closely interlinked and form ES bundles (Martín-López et al., 2012). For instance, aesthetics, spiritual enrichment, and inspiration for arts seemed to be closely interlinked in the interviews; recreation and tourism enables the renewed community identity and opportunities for education, which, in turn, strengthen the tourism sector.

The change in perceptions of whales identified in the interviews indicates an economic and socio-cultural shift from consumptive to non-consumptive uses of whales (Higham et al., 2016). This shift is at least partly facilitated by globalisation, characterised by improved access and sharing of information that affects environmental values, easier access to long distance travel, and advances in science that enabled endangered species to get global attention. These factors, combined with the economic benefits of whale watching in Húsavík, resulted in the shift in local perceptions and socio-cultural values related to whales (Einarsson, 2009; Huijbens \& Einarsson, 2018).

The concerns expressed in the interviews regarding she shift and possible disappearance of some whale species from the area are not without grounds as whale migration patterns have changed or are likely to change in the future due to climate change-related factors (Evans \& Bjørge, 2013; Salvadeo et al., 2013; Vacquié-Garcia et al., 2018). Ongoing research at the University of Iceland (2020) indicates changing behaviour of humpback whales during the last decade in Icelandic waters, where they have been staying in the winter months increasingly often.

\subsection{Academic value and implications for management}


ES researchers, users, and practitioners have called for different types of values to be included in ES assessments and policymaking (Chan, Guerry, et al., 2012; Díaz et al., 2015; Jacobs et al., 2016; Martínez et al., 2013). Van Riper and Kyle (2014) stress the need to consider diverse viewpoints to inform resource management decision-making and disentangle the conceptual and empirical relationships between multiple value concepts. Iniesta-Arandia et al. (2014) suggest socio-cultural valuation as a useful tool for prioritising ES and linking ES values to stakeholder perceptions, incorporating qualitative analysis as was done in this study. Walz et al. (2019) stress that understanding the management and decision-making context is a vital first step in carrying out management-oriented socio-cultural valuation.

Scholte et al. (2015) present a framework for integrating socio-cultural values into decisionmaking, together with monetary and ecological assessments, so that all three ES value domains are covered (Martín-López et al., 2014). Santos-Martín et al. (2017) highlight different ways in which socio-cultural ES assessment can aid in decision-making, including awareness raising, local value and knowledge recognition, addressing relational values in a particular context, conflict identification, and priority setting. A socio-cultural valuation study focused on Brazilian mangroves suggests that taking into account local users' perceptions and values in conservation policies holds the potential to make them more effective and equitable (de Souza Queiroz et al., 2017). Others, however, call for caution when including the results of this type of valuation in management decisions, as it could prove to be detrimental if the surveyed population lacks environmental knowledge about that particular ecosystem (RuizFrau et al., 2018).

An example of how this socio-cultural valuation study could aid decision-making would be if its results would be taken into consideration in the conception and planning of a marine protected area in Skjálfandi Bay, which has been a subject of local debate since 2004 (Hoyt, 2012; Vallejo, 2013). The process has been rather slow due the lack of precedent of such an area in Iceland ${ }^{9}$ and the stakeholder-led approach, which requires lengthy consultations and includes multiple interests. The results of this survey could inform this discussion in several ways: firstly, by drawing attention to the different locally formed socio-cultural benefits and values that are likely to be affected by such project; secondly, by identifying possible conflicts between different uses of the bay, e.g. industrial development and ecosystem conservation; and finally, by drawing attention to ES synergies and trade-offs and providing guidance for effective solutions for addressing them (Martín-López et al., 2012).

Furthermore, socio-cultural valuation of whale ES has the potential to inform marine spatial planning (MSP), leading to a more holistic approach (McKinley et al., 2019). This could involve accounting for different local uses of marine resources, knowledge co-production, human wellbeing effects of different scenarios (Klain \& Chan, 2012; UNESCO, 2019), and accounting for ES trade-offs in socio-cultural terms (White et al., 2012). While it is important to recognise the complexity in MSP, some consistency in methods and types of data collected in ES research would allow for broader comparisons across cases and make socio-cultural data more applicable for management (Ehler \& Douvere, 2009; McKinley et al., 2019; Ruiz-Frau et al., 2018).

\footnotetext{
${ }^{9}$ Almost all of the protected areas in Iceland are terrestrial (Petursson et al., 2016); only about $0.4 \%$ of Iceland's waters constitute marine managed areas, and none of them formal MPAs (OECD, 2019).
} 


\subsection{Study limitations}

The study suffers the typical limitations of qualitative research related to subjectivity and potential bias on the part of researchers. Designing the stakeholder map, making the interview guide, choosing which interviewees to contact, the coding of interviews, systemising the study results, and interpreting them inevitably involve a certain degree of bias (Norris, 1997). Similarly, the processes of identifying the key whale ES, interpretation and coding of the assigned values, and translating the wording of interviewees into the ES value domain typology involved some subjectivity. We tried to minimise the degree of bias by rigorously following the best practice guidelines of the chosen research methods.

A limitation that arose as the study progressed is that the final list of whale ES used in the survey was informed by the interviews, who were mostly residents of Húsavík, but the majority of survey respondents ended up being visitors. The visitors represent an important group of stakeholders and the final list of the key whale ES might have been somewhat different if they had been interviewed together with the locals. This shortcoming is alleviated to some degree by the fact that the list was also informed by the literature review by Cook et al. (2020) with a global focus on whale ES as well as observations of the researchers drawn from two weeks of community immersion.

Another shortcoming of the socio-cultural survey relates to the relatively high scores assigned to the whale ES as the respondents were able to give them any score between 0 and 5 without prioritising. This shortcoming is characteristic to other Likert-type surveys (Calvet-Mir et al., 2012; de Souza Queiroz et al., 2017; Maestre-Andrés et al., 2016) and could be at least partly corrected by a requirement to rank items from the most to the least important or to distribute scores, e.g. through the pebble distribution method.

A bias might have been created during the surveys when explanations were required for certain ES, such as regulating and maintenance. Following the explanations, these ES were valued relatively highly. On the other hand, the ES of spiritual enrichment often required explanations, yet it was ranked relatively low, so the presence of bias is not certain.

There is also a difficulty in separating whale ES from marine ES in a broader sense, especially when accounting for them in decision making. Even though it is useful to focus on a few species and analyse their socio-cultural values that are central in a particular community, it is equally important to consider outcomes in a holistic socio-ecological context when making management decisions (Brown et al., 2001; Long et al., 2015).

\section{Conclusions and possibilities for further research}

The main value of this paper lays in its subject and methodology. ES practitioners have called for ecosystem-service-based assessments, especially for marine ES on species and functional type levels. The multi-method approach applied in the study allowed for a more nuanced analysis of human wellbeing contribution of certain marine ES than a single-method approach 
would have allowed. The combination of qualitative insights and quantitative survey results uncover the multifaceted nature of human wellbeing benefits from whale ES and reflect stakeholder perceptions and values related to local marine ES.

Cultural ES and their values were most often discussed in the analysis of qualitative data, regulation and maintenance ES were the most highly valued in the socio-cultural valuation survey, and provisioning ES were given little importance in either the survey or the interviews. The study indicates that whales play an important role in the economic, social and cultural life of Húsavík, and that they are perceived as an important part of the Skjálfandi Bay ecosystem by both local residents and visitors. The fact that the existence of whales was the most highly rated whale ES indicates that a large part of the human wellbeing benefits that stem from non-use values related to these animals. Among the biggest threats to whale ES mentioned by interviewees were uncertainty caused by climate change and disturbances to whales caused by the expansion of tourism and industry.

Socio-cultural perspective adds to the depth and complexity to ES valuation. Combined with monetary and biophysical valuation, it can help to capture plural values of ecosystems. The methods used in this study are transferable to other species and ecosystems, and the results provide some interesting information about perceptions and values assigned to marine ES. This exploratory paper provides a snapshot of a point in time in the context of whale ES in Iceland, which serves as a step towards the wider application of socio-cultural valuation to marine ES in the region and globally.

Finally, the socio-cultural approach to ES valuation offers deeper and more structured insights than stakeholder-focused approaches to inform decision-making, e.g. Environmental Impact Assessments. Despite the case for including socio-cultural values in ES assessments having been made in the literature, there remains a lack of socio-cultural valuation studies, especially in the context of marine ES. Further research should aim to fill this gap while refining the methods and working towards making the results more rigorous and comparable across cases and different types of ecosystems. This would help to establish this type of valuation more firmly on the ES research agenda and aid policy makers in familiarising with and including the socio-cultural dimensions of marine resource management.

\section{Acknowledgements}

This paper has been subject to funding from NordForsk (grant number 76654) via their financial support to the Nordic Centre of Excellence ARCPATH (Arctic Climate Predictions Pathways to Resilient, Sustainable Communities) and the Doctoral Grant of the University of Iceland Research Fund. 


\section{References}

Beaumont, N. J., Austen, M. C., Atkins, J. P., Burdon, D., Degraer, S., Dentinho, T. P., ... \& Marboe, A. H. (2007). Identification, definition and quantification of goods and services provided by marine biodiversity: implications for the ecosystem approach. Marine pollution bulletin, 54(3), 253-265.

doi:10.1016/j.marpolbul.2006.12.003

Bejder, L., Samuels, A., Whitehead, H., \& Gales, N. (2006). Interpreting short-term behavioural responses to disturbance within a longitudinal perspective. Animal Behaviour, 72, 1149-1158. doi.org:10.1016/j.anbehav.2006.04.003

Bertulli, C. G., Leeney, R. H., Barreau, T., \& Matassa, D. S. (2016). Can whale-watching and whaling co-exist? Tourist perceptions in Iceland. Journal of the Marine Biological Association of the United Kingdom, 96(4), 969-977. doi:10.1017/S002531541400006X

Bessette, G. (2004). Involving the community: A guide to participatory development communication: International Development Research Centre, Ottawa.

Bock, N. (2013). Sustainable development considerations in the Arctic. In Environmental security in the Arctic Ocean (pp. 37-57). Springer, Dordrecht.

Brown, K., Adger, W. N., Tompkins, E., Bacon, P., Shim, D., \& Young, K. (2001). Trade-off analysis for marine protected area management. Ecological economics, 37(3), 417434. doi:10.1016/S0921-8009(00)00293-7

Brydon, A. (2006). The predicament of nature: Keiko the whale and the cultural politics of whaling in Iceland. Anthropological quarterly, 79(2), 225-260.

Bullock, C., Joyce, D., \& Collier, M. (2018). An exploration of the relationships between cultural ecosystem services, socio-cultural values and well-being. Ecosystem Services, 31, 142-152. doi:10.1016/j.ecoser.2018.02.020

Calvet-Mir, L., Gómez-Baggethun, E., \& Reyes-García, V. (2012). Beyond food production: Ecosystem services provided by home gardens. A case study in Vall Fosca, Catalan Pyrenees, Northeastern Spain. Ecological economics, 74, 153-160. doi:10.1016/j.ecolecon.2011.12.011

Caulfield, R. A. (1997). Greenlanders, whales, and whaling: sustainability and selfdetermination in the Arctic: Dartmouth College Press.

Chakraborty, S., Saha, S. K., \& Ahmed Selim, S. (2020). Recreational services in tourism dominated coastal ecosystems: Bringing the non-economic values into focus. Journal of Outdoor Recreation and Tourism, 30, 100279. doi:10.1016/j.jort.2020.100279

Chambers, C., Helgadóttir, G., \& Carothers, C. (2017). "Little kings": community, change and conflict in Icelandic fisheries. Maritime Studies, 16(1), 10. doi:10.1186/s40152-0170064-6

Chan, K. M., Balvanera, P., Benessaiah, K., Chapman, M., Díaz, S., Gómez-Baggethun, E., . . . Turner, N. (2016). Opinion: Why protect nature? Rethinking values and the environment. Proceedings of the National Academy of Sciences, 113(6), 1462-1465. doi:10.1073/pnas.1525002113

Chan, K. M., Guerry, A. D., Balvanera, P., Klain, S., Satterfield, T., Basurto, X., . . W Woodside, U. (2012a). Where are Cultural and Social in Ecosystem Services? A Framework for Constructive Engagement. BioScience, 62(8), 744-756. 
Chan, K. M., Satterfield, T., \& Goldstein, J. (2012b). Rethinking ecosystem services to better address and navigate cultural values. Ecological economics, 74, 8-18. doi:10.1016/j.ecolecon.2011.11.011

Chapin, F. S., Sommerkorn, M., Robards, M. D., \& Hillmer-Pegram, K. (2015). Ecosystem stewardship: A resilience framework for arctic conservation. Global environmental change, 34, 207-217. doi:10.1016/j.gloenvcha.2015.07.003

Charmaz, K., \& Belgrave, L. L. (2007). Grounded theory. The Blackwell encyclopedia of sociology.

Christiansen, F., Rasmussen, M., \& Lusseau, D. (2013). Whale watching disrupts feeding activities of minke whales on a feeding ground. Marine Ecology Progress Series, 478, 239-251.

Cook, D., Malinauskaite, L., Davíđsdóttir, B., Ögmundardóttir, H., \& Roman, J. (2020). Reflections on the ecosystem services of whales and valuing their contribution to human well-being. Ocean \& Coastal Management, 186, 105100. doi:10.1016/j.ocecoaman.2020.105100

de Souza Queiroz, L., Rossi, S., Calvet-Mir, L., Ruiz-Mallén, I., García-Betorz, S., Salvà-Prat, J., \& Meireles, A. J. d. A. (2017). Neglected ecosystem services: Highlighting the sociocultural perception of mangroves in decision-making processes. Ecosystem Services, 26, 137-145. doi:10.1016/j.ecoser.2017.06.013

Díaz, S., Demissew, S., Carabias, J., Joly, C., Lonsdale, M., Ash, N., . . Zlatanova, D. (2015). The IPBES Conceptual Framework - connecting nature and people. Current Opinion in Environmental Sustainability, 14, 1-16. doi:10.1016/j.cosust.2014.11.002

Durham, E., Baker, H., Smith, M., Moore, E., \& Morgan, V. (2014). The BiodivERsA stakeholder engagement handbook: BiodivERsA, Paris.

Ehler, C., \& Douvere, F. (2009). Marine Spatial Planning: a step-by-step approach toward ecosystem-based management. Retrieved in April 2020 from https://development.oceanbestpractices.net/bitstream/handle/11329/459/186559e .pdf?sequence $=1$

Einarsson, N. (2009). From good to eat to good to watch: whale watching, adaptation and change in Icelandic fishing communities. Polar Research, 28(1), 129-138.

Evans, P. G., \& Bjørge, A. (2013). Impacts of climate change on marine mammals. Marine Climate Change Impacts Partnership (MCCIP) Science Review, 2013, 134-148.

Gallup Iceland. (2017). Icelanders' attitude towards whale hunting. Retrieved in April 2020 from https://s3.amazonaws.com/ifawpantheon/sites/default/files/legacy/default/IFAW-Gallup-Oct2017-full-version.pdf

Glaser, B., \& Strauss, A. (1967). The Discovery of Grounded Theory. London: Weidenfeld and Nicholson, 24(25), 288-304.

Gómez-Baggethun, E., \& Martín-López, B. (2015). Ecological economics perspectives on ecosystem services valuation Handbook of Ecological Economics. Cheltenham, UK.

Government of Iceland. (2017). Reglugerð um bann við hvalveiðum á tilteknum svæðum, 1035/2017 [Laws on ban of whaling in selected areas]. Retrieved in April 2020 from https://www.stjornarradid.is/lisalib/getfile.aspx?itemid=228012d3-d514-11e7-9422005056bc530c

Greenhalgh, T., \& Peacock, R. (2005). Effectiveness and efficiency of search methods in systematic reviews of complex evidence: audit of primary sources. BMJ : British Medical Journal, 331(7524), 1064-1065. doi:10.1136/bmj.38636.593461.68 
Guđmundsdóttir, R., \& Ívarsson, A. V. (2008). Efnahagsleg áhrif ferđapjónustu á Húsavík: Tilkoma hvalaskođunar [Economic impact of tourism in Húsavík: Emergence of whale watching]. Húsavík: Pekkingarnet pingeyinga.

Haines-Young, R., \& Potschin, M. (2018). Common International Classification of Ecosystem Services (CICES) V5. 1 and guidance on the application of the revised structure. Retrieved in April 2020 from https://cices.eu

Hammerschlag, N., Schmitz, O. J., Flecker, A. S., Lafferty, K. D., Sih, A., Atwood, T. B., ... \& Cooke, S. J. (2019). Ecosystem function and services of aquatic predators in the Anthropocene. Trends in ecology \& evolution, 34(4), 369-383. doi:10.1016/j.tree.2019.01.005

Higham, J. E. S., Bejder, L., Allen, S. J., Corkeron, P. J., \& Lusseau, D. (2016). Managing whalewatching as a non-lethal consumptive activity. Journal of Sustainable Tourism, 24(1), 73-90. doi:10.1080/09669582.2015.1062020

Hoyt, E. (2012). Marine protected areas for whales dolphins and porpoises: A world handbook for cetacean habitat conservation: Routledge.

Huijbens, E. H., \& Einarsson, N. (2018). Feasting on friends: Whales, puffins, and tourism in Iceland Tourism Experiences and Animal Consumption (pp. 10-27): Routledge.

Icelandic Tourist Board. (2020). Hvalaskođun á Íslandi [Whale Watching in Iceland]. Retrieved in April 2020 from https://www.maelabordferdathjonustunnar.is/is/afthreying/hvalaskodun

IceWhale. (2015). Code of Conduct for Responsible Whale Watching. Retrieved in March 2020 from http://icewhale.is/code-of-conduct/

Iniesta-Arandia, I., García-Llorente, M., Aguilera, P. A., Montes, C., \& Martín-López, B. (2014). Socio-cultural valuation of ecosystem services: uncovering the links between values, drivers of change, and human well-being. Ecological economics, 108, 36-48. doi:10.1016/j.ecolecon.2014.09.028

IoES - The Institute of Economic Studies at the University of Iceland. (2019). Pjóðhagsleg áhrif hvalveiđa [The Economic Impact of Whaling]. Retrieved in March 2020 from http://www.ioes.hi.is/sites/hhi.hi.is/files/sjz/skyrslan-endanleg17.1.2019_0.pdf

Jacobs, S., Dendoncker, N., Martín-López, B., Barton, D. N., Gomez-Baggethun, E., Boeraeve, F., ... Washbourne, C.-L. (2016). A new valuation school: Integrating diverse values of nature in resource and land use decisions. Ecosystem Services, 22, 213-220. doi:10.1016/j.ecoser.2016.11.007

Jax, K., Barton, D. N., Chan, K. M. A., de Groot, R., Doyle, U., Eser, U., . . W Wichmann, S. (2013). Ecosystem services and ethics. Ecological economics, 93, 260-268. doi:10.1016/j.ecolecon.2013.06.008

Jóhannesson, H., Ólafsson, K., Heiðarsson, J. P., \& Sigurbjarnarson, V. (2009). Aluminium plant in Húsavík. Socio-economic Impact Assessment: Akureyri: University of Akureyri Research Centre.

Johannsdottir, L., Cook, D., \& Arruda, G. M. (2020). Systemic risk of cruise ships viewed from an Arctic and insurance perspective (IN REVIEW). Elementa: Science of the Anthropocene.

Kaltenborn, B. P., Linnell, J. D., Baggethun, E. G., Lindhjem, H., Thomassen, J., \& Chan, K. M. (2017). Ecosystem Services and Cultural Values as Building Blocks for 'The Good life'. A Case Study in the Community of Rost, Lofoten Islands, Norway. Ecological economics, 140, 166-176. doi:10.1016/j.ecolecon.2017.05.003 
Klain, S. C., \& Chan, K. M. A. (2012). Navigating coastal values: Participatory mapping of ecosystem services for spatial planning. Ecological economics, 82, 104-113. doi:10.1016/j.ecolecon.2012.07.008

Long, R. D., Charles, A., \& Stephenson, R. L. (2015). Key principles of marine ecosystembased management. Marine Policy, 57, 53-60. doi:10.1016/j.marpol.2015.01.013

Lusseau, D. (2004). The hidden cost of tourism: Detecting long-term effects of tourism using behavioral information. Ecology and Society, 9(1), 2. http://www.jstor.org/stable/26267644

Lusseau, D., \& Bejder, L. (2007). The long-term consequences of short-term responses to disturbance: Experiences from whalewatching impact assessment. International Journal of Comparative Psychology, 20, 228-236.

Maestre-Andrés, S., Calvet-Mir, L., \& van den Bergh, J. C. J. M. (2016). Sociocultural valuation of ecosystem services to improve protected area management: a multimethod approach applied to Catalonia, Spain. Regional Environmental Change, 16(3), 717-731. doi:10.1007/s10113-015-0784-3

Malinauskaite, L., Cook, D., Davíđsdóttir, B., \& Ögmundardóttir, H. (2020a). Whale ecosystem services and co-production processes underpinning human wellbeing in the Arctic: case studies from Greenland, Iceland and Norway. In Nord D. C. (Ed.). Nordic Perspectives on the Responsible Development of the Arctic: Springer.

Malinauskaite, L., Cook, D., Davíđsdóttir, B., Ögmundardóttir, H., \& Roman, J. (2020b). Willingness to pay for expansion of the whale sanctuary in Faxaflói Bay, Iceland: A contingent valuation study. Ocean and Coastal Management. doi:10.1016/j.ocecoaman.2019.105026

Malinauskaite, L., Cook, D., Davíđsdóttir, B., Ögmundardóttir, H., \& Roman, J. (2019). Ecosystem services in the Arctic: a thematic review. Ecosystem Services, 36, 100898. doi:https://doi.org/10.1016/j.ecoser.2019.100898

Martin, S. M. (2012). Whale watching in Iceland: an assessment of whale watching activities on Skjálfandi bay. Doctorral dissertation. Retrieved in April 2020 from https://skemman.is/handle/1946/12298

Martín-López, B., Gómez-Baggethun, E., García-Llorente, M., \& Montes, C. (2014). Trade-offs across value-domains in ecosystem services assessment. Ecological Indicators, 37, 220-228. doi:10.1016/j.ecolind.2013.03.003

Martín-López, B., Iniesta-Arandia, I., García-Llorente, M., Palomo, I., Casado-Arzuaga, I., Del Amo, D. G., . . . Willaarts, B. (2012). Uncovering ecosystem service bundles through social preferences. PloS one, 7(6), e38970.

Martínez, A., García-Llorente, M., Martín-López, B., Palomo, I., \& Iniesta-Arandía, I. (2013). Multidimensional approaches in ecosystem services assessment. Earth Observ. Ecosyst. Serv, 441.

Mattes, S. (2017). Save the Whale? Ecological Memory and the Human-Whale Bond in Japan's Small Coastal Villages. In I. Werkheiser \& Z. Piso (Eds.), Food Justice in US and Global Contexts: Bringing Theory and Practice Together (pp. 67-81). Cham: Springer International Publishing.

McKinley, E., Acott, T., \& Stojanovic, T. (2019). Socio-cultural Dimensions of Marine Spatial Planning. In J. Zaucha \& K. Gee (Eds.), Maritime Spatial Planning: past, present, future (pp. 151-174). Cham: Springer International Publishing. 
Nicosia, E., \& Perini, F. (2016). Ecotourism between Theory and Practice: Empirical Analysis of the Tourism Industry of Whale Watching in Húsavík (Iceland). Almatourism: Journal of Tourism, Culture and Territorial Development, 7(14), 60-105.

Nordurthing Municipality, N. (2020). Húsavík. Retrieved in March 2020 from https://www.nordurthing.is/is/mannlif/byggdarlogin/husavik

Norris, N. (1997). Error, bias and validity in qualitative research. Educational Action Research, 5(1), 172-176. doi:10.1080/09650799700200020

O'Connor, S., Campbell, R., Cortez, H., \& Knowles, T. (2009). Whale Watching Worldwide: tourism numbers, expenditures and expanding economic benefits, a special report from the International Fund for Animal Welfare. Yarmouth MA, USA, prepared by Economists at Large, 228.

OECD - Organisation for Economic Co-operation and Development. (2019). Analysing Data On Protected Areas. Retrieved in April 2020 from http://www.oecd.org/environment/indicators-modellingoutlooks/analysingdataonprotectedareas.htm

Oteros-Rozas, E., Martín-López, B., González, J. A., Plieninger, T., López, C. A., \& Montes, C. (2014). Socio-cultural valuation of ecosystem services in a transhumance socialecological network. Regional Environmental Change, 14(4), 1269-1289. doi:10.1007/s10113-013-0571-y

Parsons, E. C. M., Warburton, C. A., Woods-Ballard, A., Hughes, A., \& Johnston, P. (2003). The value of conserving whales: the impacts of cetacean-related tourism on the economy of rural West Scotland. Aquatic Conservation: Marine and Freshwater Ecosystems, 13(5), 397-415. doi:10.1002/aqc.582

Pascual, U., Balvanera, P., Díaz, S., Pataki, G., Roth, E., Stenseke, M., . . Yagi, N. (2017). Valuing nature's contributions to people: the IPBES approach. Current Opinion in Environmental Sustainability, 26-27, 7-16. doi:10.1016/j.cosust.2016.12.006

Pascual, U., Muradian, R., Brander, L., Gómez-Baggethun, E., Martín-López, B., Verma, M., . . . Eppink, F. (2010). The economics of valuing ecosystem services and biodiversity. TEEB-Ecological and Economic Foundation.

Petursson, J. G., Thorvardardottir, G., \& Crofts, R. (2016). Developing Iceland's Protected Areas: Taking Stock and Looking Ahead. Retrieved in March 2020 from https://www.researchgate.net/profile/Jon_Petursson/publication/301221726_Devel oping_Iceland's_Protected_Areas_Taking_Stock_and_Looking_Ahead/links/570ffef7 08ae74cb7d9eff20.pdf

Rasmussen, M. (2009). Whales in Skjálfandi Bay. Enviromental Impact Assessment (EIA) reports for Krafla Power Station, Bakki, Iceland, 16. Retrieved in March 2020 from https://www.skipulag.is/media/attachments/Umhverfismat/813/vidauki\%2011_hval ir.pdf

Rasmussen, M. (2014). The whaling versus whale-watching debate. In Whale-watching: Sustainable Tourism and Management, (81-94). Cambridge University Press, Cambridge.

Reed, M. S., Graves, A., Dandy, N., Posthumus, H., Hubacek, K., Morris, J., . . Stringer, L. C. (2009). Who's in and why? A typology of stakeholder analysis methods for natural resource management. Journal of Environmental Management, 90(5), 1933-1949. doi:10.1016/j.jenvman.2009.01.001

Reiter, E. (2017). The Whale Community of Husavik: Examining Perceptions \& Experiences. Doctoral dissertation, Duke University. Retrieved in March 2020 from 
https://dukespace.lib.duke.edu/dspace/bitstream/handle/10161/14199/MP\%20Fina I\%20-\%20Reiter\%202017.pdf?sequence=1

Riisager- Simonsen, C., Rendon, O., Galatius, A., Olsen, M.T. and Beaumont, N. (2020), Using ecosystem-services assessments to determine trade-offs in ecosystem-based management of marine mammals. Conservation Biology. doi:10.1111/cobi.13512

Robertsen, L. T. O. (2013). Recreational valuation of whale watching safaris, a case study from the Andøy region. Master's thesis, Norwegian University of Life Sciences, Ås.

Roman, J., Estes, J. A., Morissette, L., Smith, C., Costa, D., McCarthy, J., . . Smetacek, V. (2014). Whales as marine ecosystem engineers. Frontiers in Ecology and the Environment, 12(7), 377-385.

Ruiz-Frau, A., Krause, T., \& Marbà, N. (2018). The use of sociocultural valuation in sustainable environmental management. Ecosystem Services, 29, 158-167. doi:10.1016/j.ecoser.2017.12.013

Sakakibara, C. (2009). 'No whale, no music': Iñupiaq drumming and global warming. Polar Record, 45(4), 289-303. doi:10.1017/S0032247408008164

Salvadeo, C. J., Lluch-Cota, S. E., Maravilla-Chávez, M. O., Álvarez-Castañeda, S. T., Mercuri, M., \& Ortega-Rubio, A. (2013). Impact of climate change on sustainable management of gray whale (Eschrichtius robustus) populations: Whale-watching and conservation. Archives of Biological Sciences, 65(3), 997-1005.

Santos-Martín, F., Kelemen, E., García-Llorente, M., Jacobs, S., Oteros-Rozas, E., Barton, D. N., . . Martín-López, B. (2017). 4.2. Socio-cultural valuation approaches. In Burkhard, J. (Ed.), Mapping ecosystem services (pp. 102). Sofia: Pensoft Publishing.

Scholte, S. S. K., van Teeffelen, A. J. A., \& Verburg, P. H. (2015). Integrating socio-cultural sEcological economics, 114, 67-78. doi:10.1016/j.ecolecon.2015.03.007

Statistics Iceland. (2020). Population in urban areas. Retrieved in September 2020 from https://px.hagstofa.is/pxis/pxweb/is/Ibuar/lbuar_mannfjoldi_2_byggdir_Byggda kjarnarhverfi/MAN03200.px/table/tableViewLayout1/?rxid=588313b9-422d-4b1c81d4-8547983a9787

Strauss, A., \& Corbin, J. M. (1990). Basics of qualitative research: Grounded theory procedures and techniques: Sage Publications, Inc.

UNESCO - United Nations Educational, Scientiffic and Cultural Organisation. (2019). Balancing sustainable use and conservation through Marine Spatial Planning. Retrieved in April 2020 from http://msp.ioc-unesco.org/

University of Iceland. (2020). Hvalrekinn núna sýnir breytta hegðun hnúfubaks [Washed up whale carcass shows changing behaviour of humpback whales]. Retrieved in April 2020 from https://www.hi.is/frettir/hvalrekinn_nuna_synir_breytta_hegdun_hnufubaks?fbclid =IwAR1H9gkMPyC3gxq_f9DJzsLDrADM1TthLobGJSt9VQXIxolx46aPXDZfgqQ

Vacquié-Garcia, J., Lydersen, C., Ims, R. A., \& Kovacs, K. M. (2018). Habitats and movement patterns of white whales Delphinapterus leucas in Svalbard, Norway in a changing climate. Movement Ecology, 6(1), 21. doi:10.1186/s40462-018-0139-z

Vallejo, A. C. (2013). White Beaked Dolphin Distribution in Skjálfandi Bay, North East Iceland during the feeding season (May-September). In Proceedings of the ECS/ ASCOBANS/WDC Workshop: Towards a Conservation Strategy for White-beaked Dolphins in the Northeast Atlantic, 59-67. 
Van Riper, C. J., \& Kyle, G. T. (2014). Capturing multiple values of ecosystem services shaped by environmental worldviews: A spatial analysis. Journal of Environmental Management, 145, 374-384. doi:10.1016/j.jenvman.2014.06.014

Walz, A., Schmidt, K., Ruiz-Frau, A., Nicholas, K. A., Bierry, A., de Vries Lentsch, A., . . . Scholte, S. S. K. (2019). Sociocultural valuation of ecosystem services for operational ecosystem management: mapping applications by decision contexts in Europe. Regional Environmental Change, 19(8), 2245-2259. doi:10.1007/s10113-019-01506-7

Williams, R., Lusseau, D., \& Hammond, P. S. (2006). Estimating relative energetic costs of human disturbance to killer whales (Orcinus orca). Biological Conservation, 133(3), 301-311. doi:10.1016/j.biocon.2006.06.010

White, C., Halpern, B. S., \& Kappel, C. V. (2012). Ecosystem service trade-off analysis reveals the value of marine spatial planning for multiple ocean uses. Proceedings of the National Academy of Sciences. doi:10.1073/pnas.1114215109 


\section{Appendix 1. Stakeholder map.}

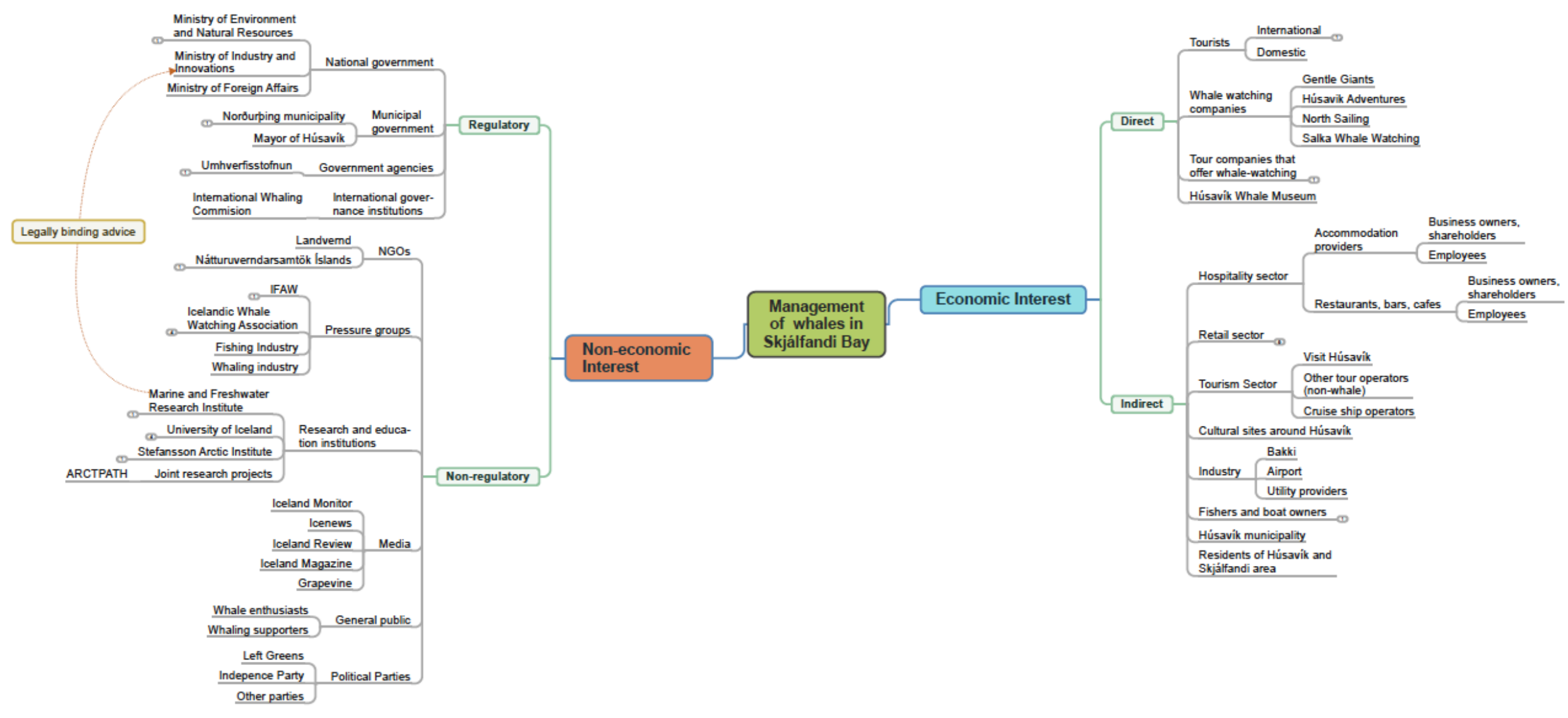

